\title{
PENERAPAN METODE EKSPERIMEN BERBASIS SCIENTIFIC APPROACH TERHADAP PERKEMBANGAN KECERDASAN LOGIS MATEMATIS ANAK USIA DINI
}

\author{
Ismiyati $^{1} \&$ Muhammad Akil Musi ${ }^{2}$ \\ ${ }^{12}$ Pendidikan Guru Pendidikan Anak Usia Dini, Universitas Negeri Makassar
}

\begin{abstract}
:
This study examines the effect of the application of the experimental method based on ascientific approach on the development of logical mathematical intelligence for Group B children in Bustanul Islamiyah Kindergarten, Makassar city. The type of research used is pre-experimental design with a quantitative approach. The sampling technique uses saturated sample technique where the population and sample are the same, namely 17 children. The indicators used are solving simple problems encountered, Doing activities that show children are able to recognize the concept of big-small, many-little, long-short, lightweight, high-low by measuring using non-standard measuring instruments and mentioning the number of objects by counting. Data collection techniques using observation and documentation techniques. The data analysis technique used descriptive analysis and nonparametric tests using the Wilcoxon difference test. Whereas in the non-parametric test, the $T$ count value is 153 and T table 35, then the T count (153)> T table value is (35) so Ho is rejected and $\mathrm{H} 1$ is accepted, meaning that there is an effect of applying the experimental method based on the scientific approach to the development of logical intelligence. Mathematically the children of Group B TK Bustanul Islamiyah Makassar City.
\end{abstract}

Keywords: Scientific approac, mathematic logical intelligence.

\begin{abstract}
Abstrak:
Studi ini menelaah tentang Pengaruh Penerapan Metode eksperimen berbasis scientific approach Terhadap perkembangan kecerdasan logis matematis anak Kelompok B TK Bustanul Islamiyah kota Makassar. Jenis penelitian yang digunakan adalah Pre-eksperimen design dengan pendekatan kuantitatif. Tehnik penyampelan menggunakan tehnik sampel jenuh dimana jumlah populasi dan sampel yang sama yaitu berjumlah 17 anak. Indikator yang digunakan yaitu melakukan kegiatan memecahkan masalah sederhana yang dihadapi, Melakukan kegiatan yang menunjukkan anak mampu mengenal konsep besar-kecil, banyaksedikit, panjang-pendek, berat-ringan, tinggi-rendah dengan mengukur menggunakan alat ukur tidak baku serta Menyebutkan jumlah benda dengan cara menghitung. Tehnik pengumpulan data menggunakan tehnik observasi dan dokumentasi. Teknik analisis data menggunakan analisis deskripsi dan uji non parametrik menggunakan uji beda Wilcoxon. Uji non parametrik didapat nilai $\mathrm{T}$ hitung sebesar 153 dan $\mathrm{T}$ tabel 35 maka diperoleh hasil $\mathrm{T}$ hitung (153) > nilai $\mathrm{T}$ tabel sebesar (35) maka Ho ditolak dan $\mathrm{H}_{1}$ diterima artinya ada pengaruh penerapan metode eksperimen berbasis scientific approach terhadap perkembangan kecerdasan logis matematis anak kelompok B TK Bustanul Islamiyah Kota Makassar.
\end{abstract}

Kata Kunci: Scientific approac, kecerdasan logis matematis. 


\section{PENDAHULUAN}

Pendidikan Anak Usia Dini merupakan suatu upaya pembinaan yang ditujukan kepada anak sejak lahir sampai dengan usia enam tahun yang dilakukan melalui pemberian rangsangan pendidikan untuk membantu pertumbuhan dan perkembangan jasmani dan rohani agar anak memiliki kesiapan dalam memasuki pendidikan lebih lanjut (Kemendikbud, 2014). Untuk itu, pendidikan anak usia dini sangat penting sebagai dasar pengembangan segala aspek perkembangan anak sebagai upaya menyiapkan anak untuk memasuki jenjang pendidikan lebih lanjut. Pemberian stimulus bagi perkembangan kecerdasan anak sejak usia dini sangat penting dilakukan. Pada anak usia dini, rangsangan dan stimulus yang diberikan akan cepat diterima oleh otak anak termasuk permberian stimulus yang mengembangkan kecerdasan logis matematis. Menurut Said dan Budimanjaya (2015: 112) "kecerdasan logis matematis adalah kemampuan pada berhitung, bernalar dan berfikir logis serta memecahkan masalah".

Upaya pengembangan kecerdasan logis matematis pada anak usia dini diharapkan dikembangkan berdasarkan minat dan cara belajar anak serta prinsip pembelajaran matematik. Prinsip yang harus diperhatikan dalam pembelajaran matematika yaitu Rencana pengalaman belajar yang kongkrit sehingga anak terlibat secara aktif, Observasi dan amati anak untuk memahami kemampuan dan minat anak, Berikan kesempatan anak belajar sesuai cara belajar anak (Utami dan Ade, 2013). Pemilihan dan penggunaan metode yang tepat diharapkan dapat mengembangkan segala aspek kecerdasan logis matematis anak.

Menurut Asmani (2015: 179) bahwa "kecerdasan logis matematis mengandalkan penalaran atau penjelajahan dalam pembelajarannya". Metode eksperimen sebagai salah satu metode yang dapat diterapkan sebagai upaya pengembangan kecerdasan logis matematis (Said dan Budimanjaya, 2015). Metode eksperimen memberikan kesempatan anak belajar aktif dan mandiri serta kongkrit melalui proses dan hasil percobaan sesuai dengan pendapat Putra (2013:132) metode eksperimen diartikan sebagai "cara belajar mengajar yang melibatkan anak dengan mengalami serta membuktikan sendiri proses dan hasil percobaan". Penggunaan metode tidak lepas dari pendekatan yang digunakan, pendekatan scientifik sebagai pendekatan pembelajaran kurikulum 2013 yang berpusat 2013 yang berpusat pada anak yang memusatkan guru untuk membimbing anak aktif mencari, mengolah dan mengkonstruksi pengetahuan yang didapatkan. Pendekatan Scientific menurut Sani (2015:53) "adalah pembelajaran yang memiliki komponen proses pembelajaran antara lain: 1) mengamati; 2) menanya; 3) mencoba/ mengumpulkan informasi; 4) menalar/ asosiasi; 5) membentuk jejaring (melakukan komunikasi)".

Berdasarkan observasi yang dilakukan pada TK Bustanul Islamiyah, proses pembelajaran masih menggunakan metode yang berpusat pada guru sehingga tidak melibatkan anak secara aktif dalam pembelajaranya dan tidak menerapkan pendekatan Scientifik sehingga tidak mengembangkan kemampuan penjelajahan dan kemampuan mengamati pada anak. Dalam pembelajaran yang mengembangkan kecerdasan logis matematis anak khususnya tentang pengenalan konsep ukuran masih kurang dan kemampuan memecahkan masalah pada anak masih kurang dikembangkan serta kemampuan berhitung anak masih rendah. Hal ini disebapkan karena metode pembelajaran yang digunakan kurang mampu mengembangkan kemampuan pemecahan masalah dan matematik anak yang belajar melalui peristiwa dan benda kongkrit. 
Melalui metode eksperimen berbasis scientific approach diharapkan dapat tercapainya pembelajaran yang berkualitas dan sesuai dengan kurikulum 2013. Membantu guru merangsang anak untuk aktif mengoptimalkan kemampuan belajar mengamati dan memecahkan masalah sekaligus mengembangkan kemampuan matematik anak. Dengan mengemabngkan dan mengoptimalkan kemampuan belajar mengamati anak melalui metode eksperimen berbasis scientific approach diharapkan terjadinya perkembangan terhadap kecerdasaan logis matematis anak.

\section{METODOLOGI}

Penelitian merupakan jenis penelitian pre-experimental design dengan menggunakan pendekatan kuantitatif. Dalam Penelitian ini terdapat dua variabel yaitu pengaruh metode eksperimen berbasis scientific approach sebagai variabel bebas (independen) dan kecerdasan logis matematis anak TK Bustanul Islamiyah sebagai variable terikat (dependen). Desain penelitian yang digunakan yaitu one group pretest-postest design.

Populasi penelitian yaitu seluruh TK Bustanul Islamiyah yang hanya terdiri dari satu kelompok berjumlah 17 anak. Tehnik penyampelan yang digunakan adalah sampling jenuh, dimana jumlah populasi yang relatif kecil sehingga diambil semua yaitu berjumlah 17 anak. Teknik pengumpulan data yang digunakan dalam penelitian ini adalah Observasi. Acuan penilaian dan pengukuran dalam observasi menggunakan bentuk kategori dimana setiap kategori tersebut diberikan bobot yang sesuai dengan tinggkatannya (Supardi, 2015). Penilaian tersebut dapat dijabarkan sebagai Baik (3), Cukup (2), Kurang (1). Dokumentasi, untuk memperoleh data langsung seperti gambaran sekolah ataupun data relevan lainya yang mendukung penelitian ini. Adapun tahapan prosedur dalam pelaksanaan penelitian ini adalah sebagai berikut :

1. Pemberian pretest yakni peneliti melakukan tes awal kecerdasan logis matematis anak sebelum perlakukan. Pretest dilakukan sebanyak dan setiap perlakukan akan dilakukan dengan 12 item observasi.

2. Pemberian perlakuan (treatment) berupa kegiatan pembelajaran menggunakan metode eksperimen berbasis scientific approach. Pemberian treatmen tersebut dengan tiga jenis kegiatan yaitu tenggelam dan terapung (konsep besar kecil dan berat ringan), percobaan dengan magnet (menghitung benda dalam percobaan, menghitung benda yang ditarik dan yang tidak dapat ditarik) dan pengukuran menggunakan alat ukur tidak baku (konsep panjang pendek, konsep tinggi rendah). Metode eksperimen berbasis scientific approach dilakukan dengan langkah-langkah percobaan awal (mengamati dan mengumpulkan informasi), pengamatan (mengamati), hipotesis awal (menanya), verifikasi (mencoba/ mengumpulkan informasi dan menanya), aplikasi konsep (mengkomunikasikan dan mengasosiasi), dan evaluasi (mengkomunikasikan).

3. Pemberian post test, peneliti melakukan proses penilaian ulang dengan instrumen yang sama terhadap kecerdasan anak setelah diberi perlakuan.

4. Analisis hasil, Kegiatan analisis hasil yakni seluruh hasil dari tahapan-tahapan sebelumnya akan disimpulkan menjadi suatu hasil penelitian.

Teknik analisis data yang digunakan untuk menganalisis data kecerdasan logis matematis adalah statisti deskriptif dan statistik non parametrik. Analisis deskriptif dimaksudkan untuk menggambarkan kecerdasan logis matematis anak didik sebelum dan 
sesudah mengikuti pembelajaran dengan menggunakan metode eksperimen berbasis scientific approach. Statistik nonparametrik digunakan dengan alasan data penelitian ini diambil dengan sistem peringkat (Ordinal) dan jumlah data yang kurang dari 30 serta data yang berdistribusi tidak normal. Menurut Sugiyono (2015a) statistik nonparametris digunakan untuk menganalisis data yang berbentuk ordinal dan tidak dilandasi persyaratan data harus berdistribusi normal serta dengan jumlah data yang kurang dari 30 .

Kriteria keputusan pengujiannya adalah $\mathrm{T}$ hitung $<\mathrm{T}$ tabel artinya Ho diterima dan H1 ditolak artinya tidak ada pengaruh penerapan metode eksperimen berbasis scientific approach terhadap perkembangan kecerdasan logis matematis anak. $\mathrm{T}$ hitung $>\mathrm{T}$ tabel artinya $\mathrm{Ho}$ ditolak dan $\mathrm{H}_{1}$ diterima artinya ada pengaruh penerapan metode eksperimen berbasis scientific approach terhadap perkembangan kecerdasan logis matematis anak. $\mathrm{Z}$ hitung $<\mathrm{Z}$ tabel artinya Ho diterima dan $\mathrm{H}_{1}$ ditolak artinya tidak ada pengaruh penerapan metode eksperimen berbasis scientific approach terhadap perkembangan kecerdasan logis matematis anak. $\mathrm{Z}$ hitung $>\mathrm{Z}$ tabel artinya $\mathrm{Ho}$ ditolak dan $\mathrm{H}_{1}$ diterima artinya ada pengaruh penerapan metode eksperimen berbasis scientific approach terhadap perkembangan kecerdasan logis matematis anak TK Bustanul Islamiyah kota Makassar.

\section{HASIL DAN PEMBAHASAN}

Sebelum memberikan perlakuan peneliti melakuan pre test terlebih dahulu untuk mendapatkan penilaian awal mengenai aspek yang diteliti atau yang ingin dikembangkan yang dalam hal ini yaitu kecerdasan logis matematis anak TK Bustanul Islamiyah Kota Makassar. Berdasarkan hasil posttest dapat diketahui bahwa persentase kemampuan pemecahan masalah anak pada kategori baik 59\%, cukup 41\% dan kurang 0\%. Persentase kemampuan anak mengenal konsep matematik anak pada kategori baik antara 53\%-94\%, cukup antara 6\%-47\% dan kurang antara 0\%. Persentase kemampuan menyebutkan jumlah benda dengan cara berhitung anak pada kategori baik 94\%, cukup 6\% dan kurang sebesar $0 \%$. Hal tersebut menunjukan persentase kecerdasan logis matematis anak berada diatas $50 \%$. Hal ini menunjukkan bahwa persentase anak yang berada pada kategori baik lebih tinggi dibandingkan persentase anak yang berada pada kategori cukup dan kurang. Adapun hasil perhitungan analisis statistik deskriptif adalah sebagai berikut:

Tabel 1. Hasil analisis deskriptif

\begin{tabular}{cc}
\hline Data Perhitungan & Data Post test \\
\hline $\mathrm{N}$ & 17 \\
\hline Rata-rata (Mean) & 32,88 \\
\hline Nilai minimal & 30 \\
\hline Nilai maksimal & 36 \\
\hline Standar Deviasi & 1,79 \\
\hline
\end{tabular}

Hasil penelitian yang diperoleh berdasarkan data dari hasil observasi sebelum dan setelah treatment, maka dapat diketahui bahwa pengaruh penggunaan metode eksperimen berbasis scientific approach terhadap kecerdasan logis matematis anak. Kemudian dilakukan uji hipotesis dengan analisis uji wilcoxon. Adapun langkah-langkah yang dilakukan adalah sebagai berikut: 
1. Data sebelum $\left(\mathrm{O}_{1}\right)$ dan sesudah $(\mathrm{O} 2)$ perlakuan ditetapkan beda selisih skor.

2. Membuat ranking dari keseluruhan jumlah anak (tanpa mempedulikan tanda) dengan cara mengurutkan nilai dari yang tertinggi sampai yang terendah, kemudian dari atas diberi angka yang menunjukkan ranking mulai dari angka 1,2, 3 dan seterusnya. Nilai yang sama harus diberikan ranking yang sama pula, yaitu dengan membagi bilangan nilai ranking secara adil pada semua pemilik nilai yang sama. Bubuhkan pada setiap ranking tanda (+ atau -).

3. Untuk menetapkan nilai $\mathrm{T}$ nilai tanda yang terkecil dijumlahkan dari kedua kelompok ranking yang memiliki tanda yang sama, dan $\mathrm{N}$ didapatkan dari jumlah sampel yang diteliti. Kemudian dilakukan perbandingan antara nilai $\mathrm{T}$ yang diperoleh dengan nilai T pada uji bertanda wilcoxon.

Berdasarkan hasil nilai $\mathrm{T}$ hitung yang didapat yaitu 153 dan $\mathrm{T}$ tabel 35 maka diperoleh hasil $\mathrm{T}$ hitung (153) $>\mathrm{T}$ tabel (35) sehingga Ho ditolak dan H1diterima artinya ada pengaruh penerapan metode eksperimen berbasis scientific approach terhadap perkembangan kecerdasan logis matematis anak. Berdasarkan hasil nilai $\mathrm{Z}$ hitung berdasarkan rumus didapat bahwa Nilai $Z$ hitung sebesar 17,7 dan $Z$ tabel (1,645) maka diperoleh hasil $\mathrm{Z}$ hitung $(17,7)>\mathrm{Z}$ tabel $(1,645)$ sehingga Ho ditolak dan H1diterima artinya ada pengaruh penerapan metode eksperimen berbasis scientificapproach terhadap perkembangan kecerdasan logis matematis anak KTK Bustanul Islamiyah kota Makassar.

\section{KESIMPULAN}

Berdasarkan data yang telah diperoleh pada saat melakukan penelitian perkembangan kecerdasan logis matemematis anak setelah dilakukan perlakuan berupa metode eksperimen berbasis scientific approach dapat disimpulkan gambaran perkembangan kecerdasan logis matematis anak kelompok B TK Bustanul Islamiah kota Makassar berupa kemampuan memecahkan masalah dan kemampuan membedakan konsep-konsep matematik seperti konsep besar, berat dan tinggi rendah serta kemampuan berhitung sesudah diberi perlakuan metode eksperimen berbasis scientific approach menunjukan bahwa terjadi perkembang kecerdasan logis matematis anak dibandingkan sebelum penerapan metode eksperimen berbasis scientific approach. Penggunaan metode eksperimen berbasis scientific approach memberikan pengaruh yang baik bagi perkembangan kecerdasan logis matematis anak kelompok B TK Bustanul Islamiyah kota Makassar.

\section{DAFTAR PUSTAKA}

Amalia, K., \& Suprapti, A. (2018). Meningkatkan Kemampuan Sains Mengenal Benda Cair melalui Metode Eksperimen. Jurnal Ilmiah POTENSIA, 3(2), 66-75.

Asmani, Jamal M. 2015. panduan praktis manajemen mutu guru paud melejetkan kecerdasan anak. Yogjakarta: Diva Press.

Dewi, A. C. (2011). Meningkatkan Kemampuan Sains Anak Usia Dini Melalui Pembelajaran Berbasis Ketrampilan Proses. Malih Peddas (Majalah Ilmiah Pendidikan Dasar), 1(2).

Herman, H., \& Rusmayadi, R. (2018). Pengaruh Metode Proyek Terhadap Kemampuan 
Kognitif Anak Di Kelompok B2 Tk Aisyiyah Maccini Tengah. PEMBELAJAR: Jurnal Ilmu Pendidikan, Keguruan, dan Pembelajaran, 2(1), 35-43.

Kementerian Pendidikan Dan Kebudayaan . 2013. Konsep Pendekatan Scientific. Jakarta: Departemen Pendidikan dan Kebudayaan.

.2014. Peraturan Pemerintah Republik Indonesia Nomor 146 Tahun 2014 tentang Kurikulum 2013 Pendidikan Anak Usia Dini. Jakarta: Departemen Pendidikan dan Kebudayaan.

Nurhaedah, N., \& Amal, A. (2017, October). Model Pembelajaran High/Scope dalam Menumbuh Kembangkan Kemampuan Anak Usia Dini. In Seminar Nasional LP2M UNM (Vol. 2, No. 1).

Putra, Sitiatava Rizema. 2013. Desain belajar mengajar berbasis sains. Yogyakarta: Diva press.

Said, A dan Budimanjaya, A. 2015. 95 Strategi Mengajar Multiple Intellegences Mengajar Sesui Kerja Otak Dan Gaya Belajar. Jakarta: Kencana.

Sani, Ridwan A. 2015. Pembelajaran Saintifik Untuk Implementasi Kurikulum 2013. Jakarta: Bumi Aksara

Sugiyono. 2015a. Metode Penelitian Pendidikan (Pendekatan Kuantitatif, Kualitatif, Dan $R \& D)$. Bandung: IKAPI.

.2015b. Statistik Non Parametrik Untuk Penelitian. Bandung: Alfabeta.

Supardi. 2015. Penilaian Autentik Pembelajaran Afektif, Kognitif Dan Psikomotor (Konsep Dan Aplikasi). Jakarta: Raja Grafindo Persada

Suryana, D. (2017). Pembelajaran Tematik Terpadu Berbasis Pendekatan Saintifik di Taman Kanak-Kanak. Jurnal Pendidikan Anak Usia Dini, 11(1), 67-82.

Utami dan Ade D. 2013. Pendidikan Anak Usia Dini. Jakarta: Universiatas Negeri Jakarta 